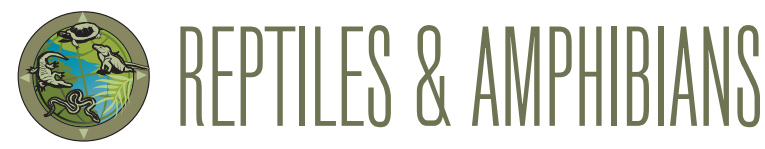

\title{
Interspecific Amplexus between a Bangladeshi Cricket Frog, Minervarya asmati (Dicroglossidae), and a Male Ornate Narrow-mouthed Frog, Microhyla ornata (Microhylidae), from Bangladesh
}

Md. Fazle Rabbe

Department of Zoology, University of Dhaka, Dhaka 1000, Bangladesh (fazlerabbedu@gmail.com)

A nurans usually attract mates by producing breeding calls, although visual and chemical signals are sometimes used as well (Belanger and Corkum 2009). Amplexus typically occurs between conspecific males and females (Wells 2007), but interspecific amplexus might occur for multiple reasons that include explosive breeding (Duellman and Trueb 1986; Machado and Bernarde 2011; Vivek et al. 2014), breeding call interference (Shahrudin 2016), lower relative female population (Wogel et al. 2005), and chemical signal disorder (Mollov et al. 2010). Although infrequent, such instances can adversely affect the population structure of frogs (Pearl et al. 2005; Amore et al. 2009).

Records of interspecific amplexus have been documented in many anuran species from throughout the world (e.g.,
Höbel 2005; Pearl et al. 2005; Mollov 2010; Streicher et al. 2010; Machado and Bernarde 2011; Vivek et al. 2014; Shahrudin 2016; Beranek 2017; González et al. 2017) but none for frogs of Bangladesh.

Between 2200 and $2230 \mathrm{~h}$ on 1 August 2017, I observed inguinal interspecific amplexus between a male Bangladeshi Cricket Frog (Minervarya asmati) and a male Ornate Narrowmouthed Frog (Microhyla ornata) that was in amplexus with a conspecific female on the Dhaka University Campus, Dhaka, Bangladesh (2343'39.95"N, 90²4'8.7"E) (Fig. 1). The frogs were on rocks covered with dead leaves in dense vegetation near three small pools used for botanical experiments. One pool was covered with water hyacinths (family Lemnoideae) whereas the others were open and exposed to sunlight. The
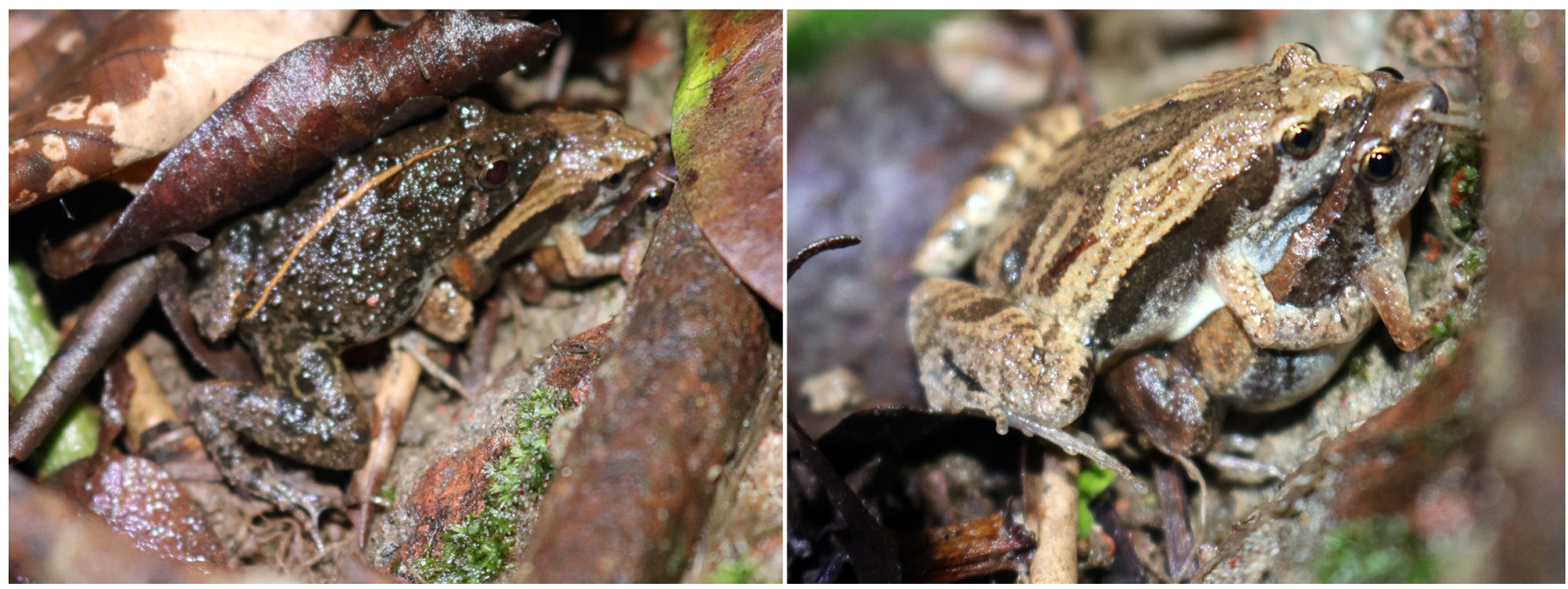

Fig. 1. Interspecific amplexus between a Bangladeshi Cricket Frog (Minervarya asmati) and a male Ornate Narrow-mouthed Frog (Microhyla ornata) that was in amplexus with a conspecific female (left) and the two Ornate Narrow-mouthed Frogs after the Bangladeshi Cricket Frog moved into nearby vegetation (right). Photographs by the author. 
male Bangladeshi Cricket Frog moved to nearby vegetation after about one minute, while the intraspecific amplexus between the two Ornate Narrow-mouthed Frogs continued for some time. Numerous individuals of Indian Bullfrogs (Hoplobatrachus tigerinus) and Asian Black-spined Toads (Duttaphrynus melanostictus) were in the vicinity.

The habitat is small in area but the density of frogs was high, presumably because few permanent bodies of water in the area are capable of supporting breeding anuran populations. Species of multiple genera often congregate in habitat suitable for breeding (Hasan et al. 2014). Previous studies suggests that the absence of niche segregation (Höbel 2005; Streicher et al. 2010) and overlapping breeding habitats (Beranek 2017) increase the likelihood of interspecific amplexus. Also, indiscriminate males of many anuran species will even clasp dead conspecifics (Ayres 2010; Mollov 2010), males of other species (Landestoy and Ortiz 2015), or inanimate objects (Streicher 2008) during the breeding season.

\section{Acknowledgements}

I thank my mentor, Professor Mohammad Firoj Jaman, for his continuous support during fieldwork on the Dhaka University Campus, and Professor Md. Kamrul Hasan for help in identifying the frogs. I also thank Mr. Nur Mohammad for assistance in the field and Fahmida Tasnim Liza for reviewing an earlier version of this note.

\section{Literature Cited}

Amore, A.D., E. Kirby, and V. Hemingway. 2009. Reproductive interference by an invasive species: An evolutionary trap? Herpetological Conservation and Biology 4: 325-330.

Ayres, C. 2010. Bufo bufo (Common Toad). Davian behavior. Herpetological Review 41: 192-193.

Belanger, R.M. and L.D. Corkum. 2009. Review of aquatic sex pheromones and chemical communication in anurans. Journal of Herpetology 43: 184-191.
https://doi.org/10.1670/08-054R1.1.

Beranek, C. 2017. Litoria dentata (Bleating Tree Frog) and Litoria peronii (Peron's Tree Frog). Interspecific amplexus. Herpetological Review 48: 411.

Duellman, W.E. and L. Trueb. 1986. Biology of Amphibians. John Hopkins University Press, Baltimore, Maryland, USA.

González, J.L.P., N. Roach, and L.A.R. Solano. 2017. Atelopus carrikeri (Guajira Stubfoot Toad) and Atelopus laetissimus (Santa Maria Harlequin Frog). Interspecific amplexus. Herpetological Review 48: 602-603.

Hasan, M.K., M.M.H. Khan, and M.M. Feeroz. 2014. Amphibians and Reptiles of Bangladesh. A Field Guide. Arranyak Foundation, Dhaka, Bangladesh.

Höbel, G. 2005. Rana clamitans (Green Frog) and Rana catesbeiana (American Bullfrog). Reproduction. Herpetological Review 36: 439-440.

Landestoy, M.A. and R. Ortíz. 2015. Rediscovery of the Eastern Crested Toad (Peltophryne fracta), with comments on conservation, vocalization, and mating behavior. Reptiles \& Amphibians 22: 50-55.

Machado, R.A. and P.S. Bernarde. 2011. Multiple and heterospecific amplexi between the toads Rhaebo guttatus and Rhinella marina (Anura: Bufonidae). Herpetology Notes 4: 167-169.

Mollov, I.A. 2010. Cases of abnormal amplexus in anurans (Amphibia: Anura) from Bulgaria and Greece. Biharean Biologist 4: 121-125.

Pearl, C.A., M.P. Hayes, R. Haycock, J.D. Engler, and J. Bowerman. 2005. Observation of interspecific amplexus between western North American ranid frogs and the introduced American Bullfrog (Rana catesbeiana) and an hypothesis concerning breeding interference. The American Midland Naturalist 154: 126-134. https:// doi.org/10.1674/0003-0031(2005)154[0126:OOIABW]2.0.CO;2.

Shahrudin, S. 2016. Interspecific amplexus between male Rhacophorus prominanus and female Polypedates leucomystax from Peninsular Malaysia. Herpetological Bulletin 135: 30-31.

Streicher, J.W. 2008. Bufo americanus (American Toad). Reproduction. Herpetological Review. 39: 75.

Streicher, J.W., C.M. Sheehy III, C.L. Cox, J. Reyes Velasco, and G.N. Weatherman. 2010. Smilisca baudinii (Mexican Treefrog) and Pachymedusa danicolor (Mexican Leaf Frog). Reproduction. Herpetological Review 41: 208.

Vivek, S., M. Dinesh, K.R. Kumar, Y. Divaker, and K.K. Sharma. 2014. Interspecies mating interactions between Duttaphrynus stomaticus (Marbled Toad) and Sphaerotheca breviceps (Indian Burrowing Frog) at the central Aravalli foothills, Rajasthan, India. Herpetology Notes 7: 139-140.

Wells, K.D. 2007. The Ecology and Behavior of Amphibians. University of Chicago Press, Chicago, Illinois, USA.

Wogel, H., P.A. Abrunhosa, and J.P. Pombal-Junior. 2005. Breeding behaviour and mating success of Phyllomedusa rohdei (Anura, Hylidae) in southeastern Brazil. Journal of Natural History 39: 2035-2045. https://doi. org/10.1080/00222930500044581. 